\title{
Перспективы применения гуминового комплекса на виноградниках Крыма
}

Магомедсайгит Расулович Бейбулатов, д-р с.-х. наук, ст. науч. сотр., заведующий лабораторией агротехнологий винограда;

Надежда Александровна Тихомирова, канд. с.-х. наук, ст. науч. сотр. лаборатории агротехнологий винограда nadegda17@bk.ru;

Наталия Александровна Урденко, канд. с.-х. наук, ст. науч. сотр. лаборатории агротехнологий винограда,

agromagarach@mail.ru;

Роман Алексеевич Буйвал, канд. с.-х. наук, науч. сотр. лаборатории агротехнологий винограда, agromagarach@mail.ru Федеральное государственное бюджетное учреждение науки «Всероссийский национальный научно-исследовательский институт виноградарства и виноделия «Магарач» РАН», Россия, Республика Крым, 298600, г. Ялта, ул. Кирова, 31.

В статье представлены результаты двухлетних исследований по изучению влияния внекорневых подкормок гуминовым препаратом нового поколения GSN-2004 HUMILIFETм (OCH-2004) на урожай и качество винограда столового сорта Мускат янтарный и технического сорта Каберне-Совиньон в условиях Южного берега Крыма. По результатам исследований 2017-2018 гг. установлено, что внекорневые подкормки изучаемым препаратом разработанной нормой 4 л/ га, способствуют увеличению урожайности винограда сорта Мускат янтарный в среднем на 23,9\%, при этом повышение урожайности составляет 2,7 т/га. Урожайность винограда сорта Каберне-Совиньон увеличивается на 26,5\%, при этом повышение урожайности составляет 2,2 т/га. Подтверждено положительное влияние внекорневых подкормок на показатели качества винограда сорта Мускат янтарный, которое выразилось в увеличении средней массы грозди у изучаемого сорта на 40,3\%, увеличении массовой концентрации сахаров в соке ягод на 5,4\% и увеличении значений глюкоацидометрического показателя (ГАП) на 15,6\%. Положительное влияние внекорневых подкормок на показатели качества винограда сорта Каберне-Совиньон выразилось в увеличении средней массы грозди на 23,0\% и увеличении массовой концентрации сахаров в соке ягод на $7,1 \%$.

Ключевые слова: внекорневые подкормки; урожай винограда; качественные показатели; вызревание побегов.

$\mathrm{B}$ ведение. ВинограА - монокультура, которая в течение срока эксплуатации погмощает из почвы необходимые Аця нее питательные вещества, значительная часть которых затем выносится с урожаем. Вследствие уменьшения плодородия почвы происходит постепенное ослабление растений, и, как результат, снижается урожайность. Большое значение ААя повышения урожайности виноградных растений имеют удобрения, которые оказывают многостороннее положительное Аействие

\section{Как цитировать эту статью:}

Бейбулатов М.Р., Тихомирова Н.А., Урденко Н.А., Буйвал Р.А Перспективы применения гуминового комплекса на виноградниках Крыма//«Магарач». Виноградарство и виноделие, 2019; 21(2); C. 122-127. DOI 10.35547/IM.2019.21.2.009

How to cite this article:

Beibulatov M.R., Tikhomirova N.A., Urdenko N.A., Buival R.A Potential areas for humic complex application in the vineyards of Crimea. Magarach. Viticulture and Winemaking, 2019; 21(2); pp. 122-127. DOI 10.35547/IM.2019.21.2.009

удк 634.85/.86.076:631.559/.816.12(470.75)

Поступила 06.02.2019

Принята к публикации 16.05.2019

(C) Авторы, 2019
O R I G I N A L A R T I C I E

\section{Potential areas for humic complex application in the vineyards of Crimea}

Magometsaigit Rasulovich Beibulatov, Nadezhda Aleksandrovna Tikhomirova, Natalia Aleksandrovna Urdenko, Roman Alekseevich Buival

Federal State Budget Scientific Institution All-Russian National Research Institute of Viticulture and Winemaking Magarach, Russian Academy of Science, 31 Kirova Str., Yalta, Crimea, Russia

The paper summarizes findings of a two-year study on the impact of foliar fertilizing with a new generation humic preparation GSN-2004 HUMILIFETM (OCH-2004) on the harvest and quality of 'Muscat Yantarniy' table grapes and 'Cabernet Sauvignon' wine grapes in the conditions of the southern coast of Crimea. The data of the 2017-2018 study established that foliar dressing with the preparation under study in the ratio of $4 \mathrm{l} / \mathrm{ha}$ increases the harvest of 'Muscat Yantarniy' grapes on average by $23.9 \%$, or by $2 \mathrm{t} / \mathrm{ha}$. The yield of 'Cabernet Sauvignon' grapes was increased by $26.5 \%$, thus increasing the harvest by $2.2 \mathrm{t} / \mathrm{ha}$. The positive impact of foliar dressing on quality indicators of 'Muscat Yantarniy' grapes was confirmed. Thus, the average cluster weight increased by $40.3 \%$, total sugars in the berry juice increased by $5.4 \%$, and gluco-acidometric index increased by $158.06 \%$. The study confirmed the positive effect of foliar dressing on quality characteristics of 'Cabernet Sauvignon' grapes, as demonstrated by a $23 \%$ increase in the average cluster weight and a $7.1 \%$ increase in the total sugars in the berry juice.

Key words: foliar dressing, harvest, quality indicators, shoot lignification.

на физиологические процессы, происходящие в растении.

В современных условиях необходима разработка высокоэффективных энергосберегающих и природоохранных приемов по увеличению производства продукции с еАиницы площаАи при меньших затратах энергии. ОАним из таких приемов, позвоцяющим сократить затраты на использование средств защиты и удобрений, является применение гуминовых препаратов.

Водорастворимые соли гуминовых кислот (гуматы) относятся к стимуляторам роста биологического происхожАения, которые обцадают свойством комплексного возАействия, направленного на нормахизацию и стимуляцию процессов, которые тормозятся ими блокируются неблагоприятными факторами внешней среды.

Гуминовые препараты нового поколения содержат цемый комплекс полезных питательных веществ (гуминовые кисло-


коусвояемых формах), отмичаются высокой биологической активностью. Эти природные вещества на 25-40\% увецичивают урожайность винограда, сокращают сроки созревания, повышают питатемьную ценность ягоА; улучшают устойчивость к болезням, заморозкам, засухе и Аругим небцагоприятным факторам. 
Наукой и практикой накопмен большой опыт по использованию органических удобрений в виноградарстве, однако Аанный вопрос остается актуацьным, ПосколькУ воспроизвоАСтво ПАОАОРОАИя почв, создание положительного бездефицитного баланса питательных веществ Аля растения - важнейшая задача земледельца [1-5].

В период с 2017 по 2018 гг. сотруАниками отдела агротехники Института «Магарач» проводились исслеАования по изучению вАияния внекорневых поАкормок гуминовым препаратом нового поколения GSN-2004 HUMILIFE ${ }^{\mathrm{TM}}$ (OCH-2004) на урожай и качество винограда столового сорта Мускат янтарный и технического сорта Каберне-Совиньон в условиях Южного берега Крыма.

Испытываемый препарат: GSN2004 HUMILIFETм (OCH-2004) - натуральный, органический препарат, иммуностимулятор, антистресс и биоактиватор роста растений. Содержит микроэлементы и кислоты в мегкоусвояемой форме.

Исследования проводимись на плоАоносящих виноградниках сорта Каберне-Совиньон 1995 года посадки. Виноградник привитой. Подвойный сорт - Берландиери х Рипариа Кобер 5ББ. Схема посадки - 3,0 х 1,5 м, форма куста среАнештамбовый Авупмечий горизонтальный корАон. Виноградник неорошаемый.

Почвенный покров на виноградниках представлен коричневыми почвами на слабощебнистых тяжелосуглинистых отложениях. Мощность гумусового горизонта - 50-60 см. Почвообразующая порода - суглинисто-каменисто-щебнистые отможения с содержанием скелета $60-70 \%$. На поверхности почвы щебень 30-50\%, камней 20-30\%. Обеспеченность почвы гумусом варьирует от низкой до средней, так содержание гумуса составляет 1,3-2,4\%. По содержанию подвижного фосфора и калия обеспеченность средняя, так $\mathrm{P}_{2} \mathrm{O}_{5}$ содержится 1,5 мг, $\mathrm{K}_{2} \mathrm{O}-22$ мг на 100 г почвы. СоАержание активной извести низкое (2,4-6,8\%), при этом реакция почвенной водной суспензии $\mathrm{pH}-8,4$. Засоление по профилю отсутствует, так сумма токсичных солей составляет 0,2-0,3 мг-экв. Об-

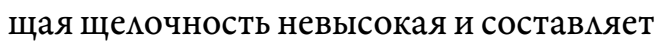
0,3 мг-экв., хмора - 0,04-0,06 мг-экв. По механическому составу почва тяжемосуглинистая, физической глины $-56,5 \%$.

Температурные показатели весеннеметнего периода в годы иссмедований
Таблица 1. Принципиальная схема полевых опытов по экспериментальной системе внесения препарата GSN-2004 HUMILIFE ${ }^{\mathrm{TM}}$ (ОСН-2004), 2018 г.

Table 1. The principal layout of field assays on experimental application of preparation GSN-2004 HUMILIFETM (OCH-2004), 2018.

\begin{tabular}{|c|c|c|c|c|}
\hline Вариант & ПиощаАь, га & $\begin{array}{l}\text { Комичество учет- } \\
\text { ных кустов в по- } \\
\text { вторности, шт. }\end{array}$ & $\begin{array}{l}\text { Норма расхода, } \\
\Lambda / \text { га, } \\
\text { м } / 20 \text { м воды }\end{array}$ & $\begin{array}{l}\text { Срок внесения } \\
\text { препарата }\end{array}$ \\
\hline \multicolumn{5}{|c|}{ Сорт Мускат янтарный (тракторное опрыскивание) } \\
\hline I & 1,00 & 15 & 4,0 & $\begin{array}{l}\text { ПереА цветением } \\
\text { После цветения } \\
\text { Начамо роста ягоА } \\
\text { Начамо созревания }\end{array}$ \\
\hline Контромь & 1,00 & 15 & - & Без обработки \\
\hline
\end{tabular}

Сорт Каберне-Совиньон (обработка ранцевым опрыскивателем)

\begin{tabular}{|c|c|c|c|c|}
\hline I & 0,09 & 15 & 100 & $\begin{array}{l}\text { ПереА цветением } \\
\text { После цветения }\end{array}$ \\
\hline II & 0,09 & 15 & 150 & $\begin{array}{l}\text { Начало роста ягоА } \\
\text { Начало созревания }\end{array}$ \\
\hline Контроль & 0,09 & 15 & - & Без обработки \\
\hline
\end{tabular}

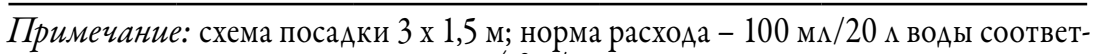
ствует норме расхода $-4,0 \Lambda /$ га

были выше среднемноголетних данных на $1,5-2,7^{\circ} \mathrm{C}$. Повышение среднесуточных температур воздуха в течение весенних и метних месяцев способствовало увеличению суммы активных температур на $263,5-543,3^{\circ} \mathrm{C}$. Количество выпавших осадков за девять месяцев года в среднем составило 465,3 мм. При этом август 2018 г. был засушиивым, с недостаточным количеством осадков; наблюдались атмосферная засуха, суховеи. В целом за период исследований сложились благоприятные метеорологические условия Аця вегетации изучаемых сортов винограАа и испытания препарата GSN-2004 HUMILIFE $^{\mathrm{TM}}(\mathrm{OCH}-2004)$.

Агротехника на виноградниках хозяйства характеризуется выполнением агротехнических мероприятий, запланированных согласно «Технологической карте хозяйства» по возделыванию винограда Аля промышленной переработки. Мероприятия по защите от вредителей и болезней проводились согласно «Плану защитных мероприятий хозяйства».

\section{Схемы полевых опытов.}

Схема опыта 1 вкцючала в себя два варианта: опыт и контроль. Вариант занимает площадь 1,0 га. Наблюдения и замеры проводи$\Lambda$ ись на трех стандартных рядах виноградника (201 куст). Аля учета бымо отобрано 45 учетных кустов. Обработки проводимись тракторным опрыскивателем ОН-400 в агрегате с трактором МТ3-80.

Схема опыта 2. Опыт полевой на производственном массиве, вкцючал в себя три варианта, из которых Ава варианта различных норм расхода испытываемого препарата и контроль. Вариант преАставлен тремя стандартными рядами виноградника - по 100 п.м, в каждом по 67 учетных кустов. В опытном варианте 134 учетных куста. Обработки проводились ранцевым опрыскивателем (табл.1).

Исследования проводились по общепринятым в виноградарстве методикам [5].

Обсуждение результатов. Результаты наблюдений за прохождением фенологических фаз сортов Мускат янтарный и Каберне-Совиньон свидетельствуют о соответствии условий Южного берега Крыма их биологическим особенностям. Соответствие природным условиям местности подтверждается при сравнительном анализе Аанных китературных источников [9]. 
Potential areas for humic complex application in the vineyards of Crimea.

В сроках наступления конкретных фенологических фаз по вариантам опытов у сорта Каберне-Совиньон размичий не бымо (табц. 2).

В ходе исследований бым ПровеАен Аисперсионный анамиз однофакторного опыта по агробиологическим показателям: нагрузка на куст; количество неразвившихся, развившихся и плодоносных побегов, соцветий, который показац, что разАичий межАу вариантами опыта нет [8] (табц. 3).

Объективными показатемями состояния растений явАяются прирост винограАного куста и степень вызревания побегов.

Изучение ростовых процессов в Аинамике показац, что прирост на учетных кустах винограда как сорта Мускат янтарный, так и сорта Каберне-Совиньон, при применении препарата GSN-2004 HUMILIFE $^{\text {тм }}$ (OCH-2004) характеризовацся стабимьным превышением наА контролем таких показателей как среА-

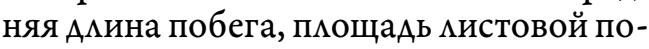
верхности и вызревание побегов.

Положительное действие изучаемого препарата выразимось в увекичении средней Алины побегов в опытных вариантах по сравнению с контролем: у сорта Мускат янтарный на 23,5\%, и у сорта Каберне-Совиньон - до 28,6\%. Наиболее интенсивный рост побегов наблюдался в опытных вариантах в фазы цветения и роста ягоА. В Аамьнейшем, в период созревания ягоА интенсивность роста побегов уменьшацась.

Пропорционацьно Алине побегов

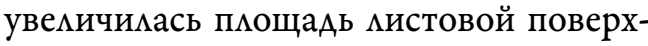
ности кустов, значения которой превосходици контромь на 23,0\% у сорта Мускат янтарный, и Ао 30,6 \% - у сорта Каберне-Совиньон.

В опыте 2 на сорте Каберне-Сови-

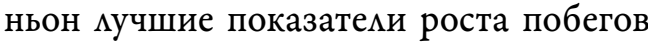

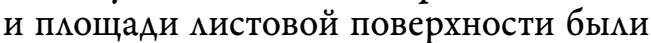
в варианте II-(150 м $\left./ 20 \wedge \mathrm{H}_{2} \mathrm{O}\right)$.

Аействие препарата GSN-2004 HUMILIFE $^{\mathrm{TM}}(\mathrm{OCH}-2004)$ выразимось в укучшении степени вызревания побегов в опытных вариантах на 11,9\% у сорта Мускат янтарный и Ао $12,7 \%$ - у сорта Каберне-Совиньон (на третью декалу августа). В опыте 2 мучшие показатели по вызреванию побегов быми в варианте I-(100 м $\left./ 20 \Lambda \mathrm{H}_{2} \mathrm{O}\right)$ (табц. 4).

Фактическая урожайность явцяется основным показателем, характеризующим продуктивность сорта винограда. Ее величина во многом зависит от условий зоны выращивания и применяемых при-
Beibulatov M.R., Tikhomirova N.A.,

Urdenko N.A., Buival R.A

VITICULTURE

Таблица 2. Фенологические наблюдения. Изучение препарата GSN-2004 HUMILIFE ${ }^{\mathrm{TM}}$ (OCH-2004), ФГУП «ПАО «Массандра», филиал «Ливадия», 2017-2018 гг.

Table 2. Phenological observations. The study of GSN-2004 HUMILIFEtM (OCH-2004) preparation, FGUP PAO Massandra, Livadiya branch, 2017-2018.

\begin{tabular}{|c|c|c|c|c|c|c|}
\hline Сорт & ГоА & $\begin{array}{l}\text { Начало } \\
\text { распуска- } \\
\text { ния глазког }\end{array}$ & $\begin{array}{l}\text { Начамо } \\
\text { цвете- } \\
\text { ния }\end{array}$ & $\begin{array}{l}\text { Начало } \\
\text { созрева- } \\
\text { ния ягоА }\end{array}$ & $\begin{array}{l}\text { Потребитель- } \\
\text { ская / техниче- } \\
\text { ская зремость }\end{array}$ & $\begin{array}{l}\text { Продукцион- } \\
\text { ный периоА, } \\
\text { Аней }\end{array}$ \\
\hline \multicolumn{7}{|l|}{ Опыт 1} \\
\hline \multirow{3}{*}{$\begin{array}{l}\text { Мускат } \\
\text { янтарный }\end{array}$} & 2017 & 19.04. & 6.06 & 31.07. & 11.08 . & 114 \\
\hline & 2018 & 13.04. & 25.05 & 19.07 & 01.08 . & 110 \\
\hline & среАнис & 15.04 & 01.06 & 25.07. & 06.08 . & 112 \\
\hline \multicolumn{7}{|l|}{ Опыт 2} \\
\hline \multirow{3}{*}{$\begin{array}{l}\text { Каберне- } \\
\text { Совиньон }\end{array}$} & 2017 & 25.04. & 9.06 & 10.08 & 25.09 & 153 \\
\hline & 2018 & 18.04 . & 31.05. & 30.07 . & 9.09 . & 144 \\
\hline & среАние & 21.04 & 04.06. & 05.08 . & 17.09. & 148 \\
\hline
\end{tabular}

Таблица 3. Агробиологические учеты (фон). Изучение препарата GSN-2004 HUMILIFE ${ }^{\text {тм }}$ (OCH-2004) ФГУП «ПАО «Массандра», филиал «Ливадия», 2017-2018 гг. (средние значения)

Table 3. Agrobiological calculations. The study of GSN-2004 HUMILIFETM (OCH-2004) preparation FGUP PAO Massandra, Livadiya branch, 2017-2018 (mean values).

\begin{tabular}{|c|c|c|c|c|c|c|c|c|c|c|}
\hline \multirow[t]{2}{*}{ Вариант } & \multirow{2}{*}{$\begin{array}{l}\text { Нагрузка } \\
\text { куста, гл. }\end{array}$} & \multicolumn{2}{|c|}{$\begin{array}{l}\text { Нагрузка } \\
\text { побегами } \\
\text { на куст }\end{array}$} & \multicolumn{2}{|c|}{$\begin{array}{l}\text { Нераз- } \\
\text { вившиеся } \\
\text { гмазки }\end{array}$} & \multicolumn{2}{|c|}{$\begin{array}{l}\text { Пцодонос- } \\
\text { ные побеги }\end{array}$} & \multirow{2}{*}{$\begin{array}{l}\text { Коли- } \\
\text { чество } \\
\text { соцве- } \\
\text { тий, } \\
\text { шт. }\end{array}$} & \multicolumn{2}{|c|}{$\begin{array}{l}\text { Коэффици- } \\
\text { ент }\end{array}$} \\
\hline & & шт. & $\%$ & шт. & $\%$ & шт. & $\%$ & & $\mathrm{~K}_{1}$ & $\mathrm{~K}_{2}$ \\
\hline \multicolumn{11}{|c|}{ Сорт Мускат янтарный } \\
\hline Опыт & 43,4 & 34,8 & 79,8 & 8,6 & 20,2 & 27,4 & 77,8 & 32,0 & 0,91 & 1,16 \\
\hline Контромь & 40,0 & 30,8 & 76,5 & 9,2 & 23,5 & 25,4 & 82,9 & 28,1 & 0,91 & 1,11 \\
\hline $\mathrm{HCP}_{05}$ & 8,14 & 5,99 & - & 1,49 & - & 3,66 & - & 2,12 & 0,26 & 0,10 \\
\hline \multicolumn{11}{|c|}{ Сорт Каберне-Совиньон } \\
\hline Опыт & 51,5 & 41,3 & 80,2 & 10,2 & 19,7 & 28,5 & 69,1 & 38,5 & 0,94 & 1,36 \\
\hline Контромь & 53,5 & 41,5 & 77,6 & 12,0 & 22,3 & 26,5 & 63,7 & 34,8 & 0,83 & 1,31 \\
\hline $\mathrm{HCP}_{05}$ & 8,22 & 6,14 & - & 1,72 & - & 5,90 & - & 2,81 & 0,30 & 0,16 \\
\hline
\end{tabular}

Таблица 4. Динамика роста побегов и площади листовой поверхности куста. Изучение препарата GSN-2004 HUMILIFEтм (OCH-2004), ФГУП «ПАО «Массандра», филиал «Ливадия», 2017-2018 гг. (средние значения) Table 4. Shoot and leaf surface area growth rate. The study of GSN-2004 HUMILIFETM (OCH-2004) preparation, FGUP PAO Massandra, Livadiya branch, 2017-2018 (mean values).

\begin{tabular}{|c|c|c|c|c|c|c|c|}
\hline \multirow{3}{*}{ Вариант } & \multicolumn{7}{|c|}{ Аата проведения замеров } \\
\hline & \multicolumn{2}{|l|}{ июнь } & \multicolumn{2}{|l|}{ июАь } & \multicolumn{3}{|l|}{ август } \\
\hline & $\mathrm{L}, \mathrm{cm}$ & $S, \mathrm{~m}^{2}$ & $\mathrm{~L}, \mathrm{~cm}$ & $S, \mathrm{~m}^{2}$ & $\mathrm{~L}, \mathrm{~cm}$ & $\begin{array}{l}\text { вызревшая } \\
\text { часть, см }\end{array}$ & $\begin{array}{l}\text { вызревание } \\
\text { побегов, \% }\end{array}$ \\
\hline \multicolumn{8}{|c|}{ Сорт Мускат янтарный } \\
\hline Опыт & 73,7 & 3,70 & 140,7 & 8,33 & 147,5 & 132,9 & 90,1 \\
\hline Контроль & 60,3 & 3,18 & 114,6 & 6,77 & 119,4 & 93,4 & 78,2 \\
\hline $\mathrm{HCP}_{05}$ & 12,31 & 0,68 & 11,57 & 0,49 & 27,55 & 25,14 & 5,16 \\
\hline \multicolumn{8}{|c|}{ Сорт Каберне-Совиньон } \\
\hline $\mathrm{I}-\left(100{ }_{\Lambda} / 20 \Lambda_{\mathrm{H}_{2}} \mathrm{O}\right)$ & 105,6 & 6,11 & 221,4 & 9,57 & 238,1 & 226,8 & 95,2 \\
\hline $\mathrm{II}-\left(150 \mathrm{M} \Lambda / 20 \Lambda_{\mathrm{H}} \mathrm{O}\right)$ & 87,7 & 5,52 & 225,8 & 9,69 & 237,7 & 220,8 & 92,8 \\
\hline Контроль & 77,7 & 5,02 & 176,5 & 7,42 & 185,2 & 152,9 & 82,5 \\
\hline $\mathrm{HCP}_{05}$ & 11,03 & 0,77 & 10,69 & 0,57 & 26,13 & 27,55 & 6,32 \\
\hline
\end{tabular}

Примечание: L - среАняя Алина побегов, см; S - площадь мистьев, ${ }^{2}$

емов агротехники, одним из которых явцяется внесение удобрений.

Оценка урожая винограда изучаемых сортов вкцючама в себя подсчет количества гроздей на куст, определение среАней массы 
Таблица 5. Величина и качество урожая при применении внекорневых подкормок препаратом GSN-2004 $\left(\right.$ HUMILIFE $\left.^{\mathrm{TM}}\right)$ на столовом сорте Мускат янтарный, ФГУП «ПАО «Массандра», филиал «Ливадия», $2017-18$ гг. (средние значения)

Table 5. Yield volume and quality after foliar dressing with GSN-2004 (HUMILIFETm) preparation on table cultivar 'Muskat Yantarniy', FGUP PAO Massandra, Livadiya branch, 2017-2018 (mean values).

\begin{tabular}{|c|c|c|c|c|c|c|c|}
\hline \multirow{2}{*}{ Вариант } & \multicolumn{2}{|c|}{ Урожайность } & \multirow{2}{*}{$\begin{array}{l}\text { СреАняя масса } \\
\text { грозАи, г }\end{array}$} & \multirow{2}{*}{$\begin{array}{l}\text { Продуктивность по- } \\
\text { бега (ПП), г/побег }\end{array}$} & \multicolumn{2}{|c|}{ Массовая концентрация в соке ягоА } & \multirow{2}{*}{ ГАП } \\
\hline & с куста, кг & т/га & & & сахаров, г/АM ${ }^{3}$ & титр. кислот, г/Ам ${ }^{3}$ & \\
\hline \multicolumn{8}{|c|}{ Сорт Мускат янтарный } \\
\hline Опыт & 7,0 & 14,0 & 307,1 & 276,9 & 194,5 & 4,1 & 47,5 \\
\hline Контроль & 5,6 & 11,2 & 218,9 & 200,4 & 184,5 & 4,9 & 41,1 \\
\hline $\mathrm{HCP}_{05}$ & 1,20 & - & 11,63 & 7,11 & 6,66 & 0,17 & - \\
\hline \multicolumn{8}{|c|}{ Сорт Каберне-Совиньон } \\
\hline $\mathrm{I}-\left(100{ }_{\mathrm{M}} / 2 \mathrm{~N}_{\Lambda} \mathrm{H}_{2} \mathrm{O}\right)$ & 5,2 & 10,5 & 146,2 & 136,6 & 240,5 & 8,2 & 29,3 \\
\hline II- $\left(150 \mathrm{M \Lambda} / 20 \wedge \mathrm{H}_{2} \mathrm{O}\right)$ & 5,0 & 10,0 & 143,0 & 134,4 & 229,0 & 8,4 & 27,3 \\
\hline Контроль & 4,1 & 8,3 & 118,9 & 98,8 & 224,5 & 9,5 & 23,6 \\
\hline $\mathrm{HCP}_{05}$ & 1,29 & - & 12,88 & 9,45 & 7,61 & 0,16 & - \\
\hline
\end{tabular}

Примечание: количество кустов при 10\%-ной изреженности насаждений составмяет 200 шт./га.

грозАи, урожая с куста и перерасчет его на гектар, а также проведение механического анациза гроздей по вариантам опыта.

Исследованиями установлено, что внекорневые подкормки препаратом GSN-2004 HUMILIFE $^{\mathrm{TM}}$ (ОСН-2004) положительно повцияли на величину и качество урожая изучаемых сортов. Это вырази$\Lambda$ ось в прибавке урожая и улучшении его качественных показатемей. У сорта Мускат янтарный разница по количеству урожая между опытным вариантом и контролем в среАнем за годы исследований состави$\Lambda$ а 1,4 кг с куста (25,0\%), а у сорта Каберне-Совиньон - 0,9-1,1 кг с куста (22,0-26,8\%). Прибавка урожая составима 2,7 и 2,2 т/га соответственно. Увемичение урожая с куста связано с увеличением средней массы грозАи в опытном варианте на 88,2 г (40,3\%) - у сорта Мускат янтарный и Ао 27,3 г (23,0\%) - у сорта Каберне-Совиньон. При этом по результатам учета урожая 2018 г. среАняя масса грозди, и, соответственно, прибавка урожая в опытном варианте быма ниже значений предыдущего года на 2,2 и 1,6 т/га. Недобор массы грозди обусловими аномамьно высокая температура в июле и августе, недостаток осаАков, атмосферная засуха, суховеи.

Разница значений продуктивности побегов (ПП) межАу опытными вариантами и контромем у изучаемых сортов составима $38,2 \%$.

Поцожительное вцияние внекорневых подкормок препаратом GSN-2004 HUMILIFE ${ }^{\mathrm{TM}}(\mathrm{OCH}-2004)$ на качественные показатели винограда изучаемых сортов выразицось в увеличении массовой концентрации сахаров в соке ягод в опытных вариантах на 5,4 и 7,1\% при снижении количества титруемых кислот.

По резуиьтатам исследований на изучаемых сортах бым рассчитан глюкоацидометрический показатель (ГАП) - величина, позволяющая оценить соотношение сахаров и кислот в соке ягоА винограда. При применении внекорневых подкормок значения Аанного показателя повысицись в опытном варианте по сравнению с контролем у сорта Мускат янтарный на 15,6\%; у сорта Каберне-Совиньон - на 24,1\% (табл. 5 , рис. 1).

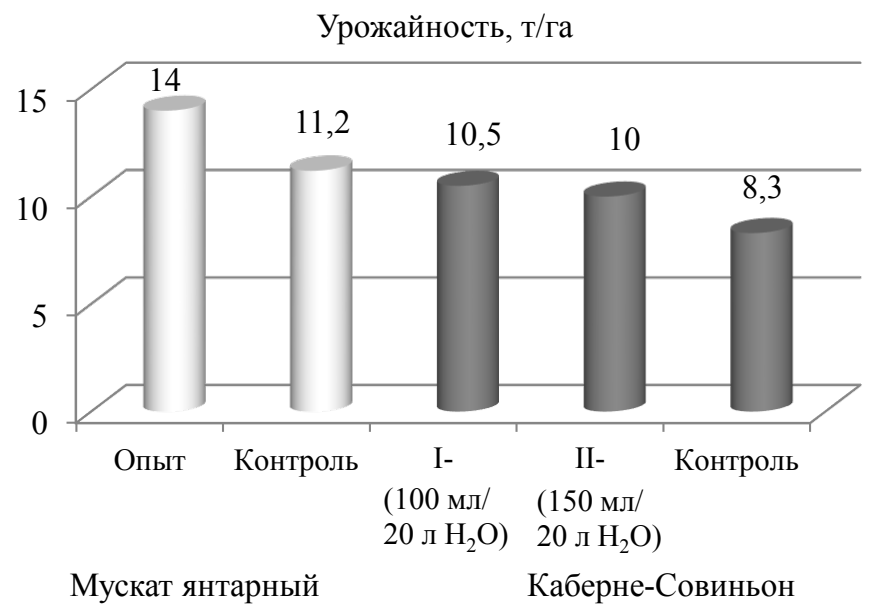

Рис. 1. Урожайность сортов винограда при применении внекорневых подкормок препаратом GSN-2004 HUMILIFE ${ }^{\text {тм }}$ (ОСН-2004), ФГУП «ПАО «Массандра», филиал «Ливадия», 2017-18 гг. (средние значения)

Fig. 1. The vine yield of various cultivars after foliar fertilizing with GSN-2004 HUMILIFETM (OCH-2004) preparation, FGUP PAO Massandra, Livadiya branch, 2017-2018 (mean values).

Аця характеристики увологических показателей исследуемых сортов винограда проводился механический анализ гроздей, вкмючающий в себя изучение отАемьных структурных эмементов грозАи и ягоды.

Механический анализ грозАей винограАа исследуемых сортов показал положительное виияние внекорневых подкормок препаратом GSN-2004 HUMILIFE $^{\text {тм }}$ (OCH-2004) на такие увоцогические показатели как масса ягод в грозАи и масса 100 ягоА. Основные увологические показатели грозАи и ягод в вариантах опыта превосходики Аанные показатели в контроцьных вариантах.

В опытных вариантах при применении препарата GSN-2004 (HUMILIFE ${ }^{\mathrm{TM}}$ ) среАняя масса ягоА в грозАи сорта Мускат янтарный увеличимась по сравнению с контролем на 88,2 г (40,3\%), а масса 100 ягоА - на 31,9 г (19,4\%), при этом значение ягодного показателя снизимось на $30,3 \%$.

В опытных вариантах на сорте Каберне-Совиньон среАняя масса ягоА в грозАи увеличимась по 
Таблица 6. Механический анализ грозди сортов винограда при применении препарата GSN-2004 HUMILIFE ${ }^{\text {тм }}$ (ОСН-2004), «ПАО «Массандра», филиал «Ливадия», 2017-2018 гг.

Table 6. Bunch mechanical analysis of vine cultivars after application of GSN-2004 HUMILIFETM (OCH-2004) preparation, FGUP PAO Massandra, Livadiya branch, 2017-2018 (mean values).

\begin{tabular}{|c|c|c|c|c|c|c|c|c|c|c|c|}
\hline Вариант & $\begin{array}{l}\text { Масса } \\
\text { грозАи, г }\end{array}$ & $\begin{array}{l}\text { Мacca } \\
\text { ягоА, Г }\end{array}$ & $\begin{array}{l}\text { Число ягоА } \\
\text { в грозАи, } \\
\text { шт }\end{array}$ & $\begin{array}{l}\text { Масса } \\
\text { гребня, г }\end{array}$ & $\begin{array}{l}\text { Масса } \\
100 \text { ягоА, } \\
\text { г }\end{array}$ & $\begin{array}{l}\text { Масса } \\
\text { семян, г }\end{array}$ & $\begin{array}{l}\text { Число } \\
\text { семян, } \\
\text { шт }\end{array}$ & $\begin{array}{l}\text { Масса } 100 \\
\text { семян, г }\end{array}$ & $\begin{array}{l}\text { Масса ко- } \\
\text { жицы, г }\end{array}$ & $\begin{array}{l}\text { Ягодный } \\
\text { показатемь }\end{array}$ & $\begin{array}{l}\text { Показатель } \\
\text { строения }\end{array}$ \\
\hline \multicolumn{12}{|c|}{ Сорт Мускат янтарный } \\
\hline Опыт & 303,5 & 297,3 & 149,4 & 6,3 & 198,8 & 7,0 & 184,5 & 3,8 & 24,2 & 47,2 & 53,2 \\
\hline Контроль & 226,7 & 222,3 & 137,4 & 4,5 & 161,9 & 5,7 & 174,6 & 3,3 & 21,4 & 60,5 & 45,4 \\
\hline $\mathrm{HCP}_{05}$ & 13,89 & 10,21 & 5,77 & 0,54 & 5,16 & 0,07 & 0,13 & 0,21 & 0,22 & - & - \\
\hline
\end{tabular}

Сорт Каберне-Совиньон

\begin{tabular}{|c|c|c|c|c|c|c|c|c|c|c|c|}
\hline $\begin{array}{l}\mathrm{I}-(100 \mathrm{M} \Lambda / 20 \Lambda \\
\left.\mathrm{H}_{2} \mathrm{O}\right)\end{array}$ & 159,8 & 151,8 & 102,7 & 8,0 & 147,6 & 3,1 & 120,9 & 2,6 & 26,6 & 64,3 & 18,9 \\
\hline $\begin{array}{l}\text { II- }(150 \mathrm{M} \Lambda / 20 \Lambda \\
\left.\mathrm{H}_{2} \mathrm{O}\right)\end{array}$ & 158,5 & 150,7 & 106,0 & 7,8 & 142,1 & 3,0 & 133,4 & 2,2 & 25,7 & 66,9 & 19,3 \\
\hline Контромь & 120,4 & 113,2 & 98,1 & 7,2 & 115,3 & 2,7 & 149,6 & 1,8 & 23,4 & 81,5 & 15,8 \\
\hline $\mathrm{HCP}_{05}$ & 11,28 & 9,16 & 6,96 & 0,61 & 4,33 & 0,08 & 0,11 & 0,19 & 0,27 & - & - \\
\hline
\end{tabular}

сравнению с контролем до 39,4 г (32,7\%), а масса 100 ягоА - Ао 32,3 г (28,0\%), при этом значение ягодного показателя снизилось до 26,7\% (табц. 6, рис. 2).

Существенность разницы межАу значениями показателей продуктивности и качества винограда у изучаемых сортов в вариантах опыта подтверждается Аисперсионным анацизом данных.

В результате проведенных в 2017-2018 годах исслеАований изучено влияние внекорневых поАкормок препаратом GSN-2004 HUMILIFE $^{\text {тм }}$ (OCH-2004) на продуктивность и качество столового винограда сорта Мускат янтарный и технического сорта винограда Каберне-Совиньон в условиях Южного берега Крыма.

По результатам Авухлетних исследований установцено положитецьное вцияние внекорневых поАкормок препаратом GSN-2004 HUMILIFE $^{\text {тм }}$ (OCH2004) на основные количественные и качественные показатеми урожая изучаемых сортов, которое выразимось в слеАующем.

1. Внекорневые подкормки препаратом GSN2004 HUMILIFE $^{\mathrm{Tм}}(\mathrm{OCH}-2004)$ нормой 4,0 $\Lambda /$ га, согласно разработанной схеме, способствуют увецичению урожая винограда сорта Мускат янтарный в среднем на 25,0\%, а сорта Каберне-Совиньон - на $26,5 \%$, при этом прибавка урожая составцяет 2,8 и 2,2 т/га соответственно.

3. ПодтвержАено положительное вмияние внекорневых подкормок на показатели качества винограда изучаемых сортов, которое выразимось в увеличении среАней массы грозАи на 40,3\% и увемичении массовой концентрации сахаров в соке ягоА на 5,4\% у сорта Мускат янтарный. Положитемьное вмияние внекорневых подкормок на показатели качества винограда сорта Каберне-Совиньон вырази$\Lambda$ ось в увецичении среАней массы грозАи на 23,0\% и увеличении массовой концентрации сахаров в соке ягод на 7,1\%.

4. Установлено положительное влияние внекорневых подкормок препаратом GSN-2004 HUMILIFE $^{\mathrm{TM}}$ (OCH-2004) на увомогические показатели грозАи и ягоА изучаемых сортов винограАа. У

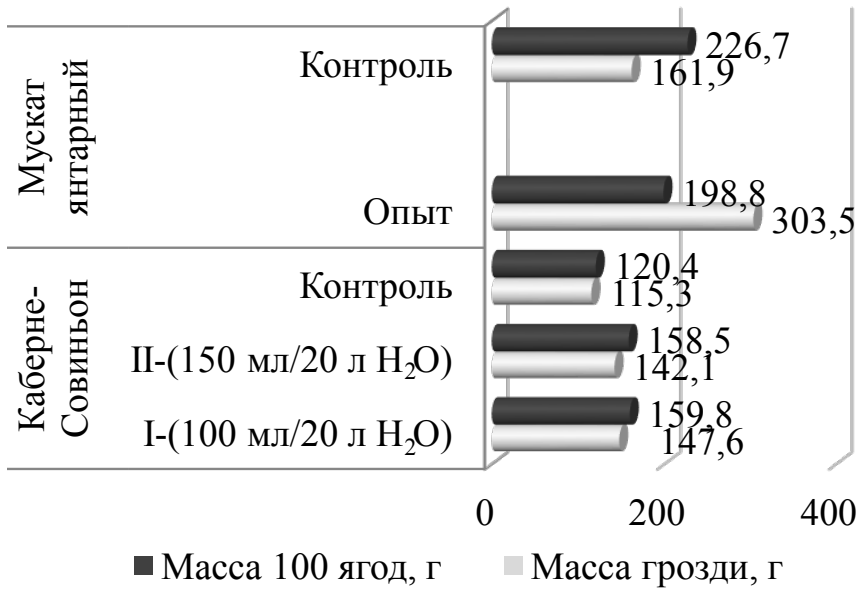

Рис. 2. Увологические показатели грозди сортов винограда при применении внекорневых подкормок препаратом GSN2004 HUMILIFE $^{\mathrm{TM}}$ (ОСН-2004), ФГУП «ПАО «Массандра», филиал «Ливадия», 2017-18 гг. (средние значения)

Fig. 2. Bunch uvological performance of grapevine cultivars after foliar fertilizing with GSN-2004 HUMILIFETM (OCH-2004), FGUP PAO Massandra, Livadiya branch, 2017-2018 (mean values).

сорта Мускат янтарный масса 100 ягод увеличимась по сравнению с контролем в среднем на $22,8 \%$, а значение ягодного показателя снизилось на 28,2\%, что обеспечимо кучшие товарные качества винограда. У сорта Каберне-Совиньон масса 100 ягод в среАнем увеличимась Ао 28,0\%. Показатемь строения увемичивался до 19,6\%, а значение ягодного показателя снизицось Ао 26,7\% по сравнению с контромем. ОПтимальные значения увологических показателей изучаемых сортов обеспечими внекорневые подкормки с нормой расхода препарата 4,0 $/$ га $(100$ м $/ 20 \Lambda$ $\left.\mathrm{H}_{2} \mathrm{O}\right)$.

5. Установлено, что 4-кратные внекорневые поАкормки препаратом GSN-2004 $\mathrm{HUMILIFE}^{\mathrm{TM}}$ (OCH2004) активизируют ростовые процессы. СреАняя Алина побегов у исследуемых сортов увемичивается на 23,5-28,6\%, а вызревание побегов улучшается на 11,9-12,7\%. Наиболее интенсивный рост побегов наблюдался в опытных вариантах с нормой расхода препарата 4,0 $/$ га $\left(100\right.$ м $\left./ 20 \Lambda \mathrm{H}_{2} \mathrm{O}\right)$. 
Таким образом, Аля повышения урожайности и умучшения качества столового винограда сорта Мускат янтарный и технического сорта Каберне-Совиньон рекомендуется:

- применять 4-кратные внекорневые подкормки препаратом GSN-2004 HUMILIFE ${ }^{\mathrm{TM}}(\mathrm{OCH}-2004)$ с нормой расхода препарата $4,0 \Lambda /$ га, согласно разработанной схеме: перед цветением, после цветения, послеАующие Аве подкормки - через 14 Аней;

- совмещать внекорневые подкормки препаратом GSN-2004 HUMILIFE ${ }^{\mathrm{TM}}$ (OCH-2004) с мероприятиями по защите растений от вреАителей и болезней Аля повышения производительности техники и сокращения производственных затрат.

Источник финансирования

\section{Не указан.}

\section{Financing source}

Not specified.

\section{Конфликт интересов}

Не заявлен.

\section{Conflict of interests}

Not declared.

\section{Список литературы / References}

1. Бейбулатов, М. Р. Почвомодифицирующие органоминеральные удобрения на виноградниках Крыма / М.Р. Бейбулатов, Н.А. Тихомирова, Р.А. Буйвал, С.В. Михайлов // Субтропическое и декоративное садоводство: Научные труды ГНУ ВНИИЦиСК РАСХН. - Сочи, 2013. - Т. 49. - С. 306-313.

Beibulatov M.R., Tikhomirova N.A., Buival R.A., Mikhailov S.V. Pocbvomodifitsiruyushchie organomineral'nye udobreniya na vinogradnikakh Kryma [ Soil-modifying organomineral fertilizers in the vineyards of Crimea] // Subtropicheskoe $i$ dekorativnoe sadovodstvo: Nauchnye trudy GNU VNIITSiSK RASKHN [ Subtropical and Ornamental Horticulture: Scientific Works of the GNU VNIITsiSK RAAS]. Sochi, 2013. T. 49. pp. 306-313. (in Russian)

2. Моисеева, Т. В. Биологические препараты и регуляторы роста растений в сельском хозяйстве / Т.В. Моисеева // Сб. шестой международной научно-практической конференции Radostim, Краснодар: ФГБОУ ВО «Кубанский государственный аграрный университет». $-2010 .-$ C. 3 .

Moiseeva T.V. Biologicheskie preparaty i regulyatory rosta rastenij v sel'skom khozyajstve [Biological preparations and plant growth regulators in agriculture] Sbornik shestoj mezhdunarodnoj nauchnoprakticheskoj konferentsii Radostim, Krasnodar: FGBOU VO «Kubanskiy gosudarstvennyi agrarnyi universitet, [Proceedings of the sixth international scientific-practical conference Radostim, Krasnodar: FSBEI HE "Kuban State Agrarian University]. 2010. P. 3. (in Russian)

3. Бейбулатов, М.Р. Удобрения для внекорневой подкормки на виноградниках Крыма / М.Р. Бейбулатов, А.П. Игнатов, Н.А. Тихомирова, Н.А. Урденко, Р.А. Буйвал, Т.В. Фирсова // Виноградарство и виноделие. - 2006. - Т. 36. - С. 49-54.

Beibulatov M.R., Ignatov A.P., Tikhomirova N.A., Urdenko N.A., Buival R.A., Firsova T.V. Udobreniya dlya unekornevoj podkormki na vinogradnikakb Kryma [Fertilizers for foliar feeding in the vineyards of Crimea]// Vinogradarstvo i vinodelie [Viticulture and winemaking]. 2006. V. 36. P. 49-54. (in Russian)

4. Бейбулатов, М.Р. Применение гуминовых препаратов нового поколения на виноградниках Южного берега Крыма / М.Р. Бейбулатов, Р.А. Буйвал, Н.А. Тихомирова, Н.А. Урденко // Проблемы рационального природопользования и пути их решения: сборник материалов Всероссийской научно-практической конференции, посвященной 45-летию ФГБОУ ВО «ДГТУ». - 2018. - С. 19-27.
Бейбулатов М.Р., Тихомирова Н.А.,

УрАенко Н.А., БуйваА Р.А.

Beibulatov M.R., Buival R.A., Tikhomirova N.A., Urdenko N.A. Primenenie guminovykh preparatov novogo pokoleniya na vinogradnikakb Yuzhnogo berega Kryma [The use of humic preparations of a new generation in the vineyards of the South Coast of Crimea] Problemy ratsional'nogo prirodopol'zovaniva i puti ikb resheniya: sbornik materialov Vserossiyskoy nauchno-prakticheskoy konferentsii, posuyashchennoy 45-letiyu FGBOU VO «DGTU» [Problems of environmental management and ways to solve them: Proceedings of the All-Russian scientific-practical conference dedicated to the 45 th anniversary of FSBEI HE «DSTU»]. 2018. pp. 19-27. (in Russian)

5. Кравченко, Р.В. Продуктивность винограда технического сорта Саперави на фоне применения лигногуматов «А» / Р.В. Кравченко, П.П. Радчевский, А.В. Прах. - Научный журнал КубГАУ, №92(08). - 2013. - Режим доступа: http://ej.kubagro.ru/2013/08/pdf/83.pdf.

Kravchenko R.V., Radcherskiy P.P., Prakb A.V. Produktivnost' vinograda tekbnicheskogo sorta Saperavi na fone primeneniva lignogumatov «A». Nauchniy zhurnal KubGAU, №92(08). - 2013. - Rezhim dostupa: http://ej.kubagro.ru/2013/08/pdf/83.pdf. (in Russian)

6. Виноград, все о винограде. Сорта. Столовые сорта. [Электронные ресурсы] - Режим доступа: http: vinograd.info/sorta/stolovye/pg-12. html.

Vinograd, use o vinograde. Sorta. Stolovye sorta [Grapes, all about grapes. Varieties. Table varieties]. Elektronnye resursy - Rezbim dostupa [Electronic resources - Access Mode:]: httr: vinograd.info/ sorta/stolovye/pg-12.html. (in Russian)

7. Докучаева, Е.Н. Сорта Винограда / Е.Н. Докучаева, Е.С. Комарова, Н.Н. Пилипенко и др.. - К.: Урожай, 1986. - 272 с.

Dokuchaeva E.N., Komarova E.S., Pilipenko N.N. Sorta Vinograda [Varieties of grapes ]. - Kiev: Urozhaj. 1986. 272 p. (in Russian)

8. Доспехов, Б.А. Методика полевого опыта / Б.А. Доспехов. - М.: Агропромиздат, 1985. - 351 с.

Dospekhov B.A. Metodika polevogo opyta [Field technique] Moscow: Agropromizdat. 1985. 351 p. (in Russian)

9. Рябов, В.А. Агроклиматологическая оценка условий произрастания плодовых культур в Крыму / В.А. Рябов, Н.Е. Опанасенко, В. В. Антюфеев. - Ялта, 2002. - 28 с

Ryabov V.A., Opanasenko N.E., Antyufeev V.V. Agroklimatolo-gicheskaya otsenka uslovij proizrastaniya plodovykb kul'tur v Krymu. Yalta. 2002. 28 p. (in Russian)

10. Методические рекомендации по агротехническим исследованиям в виноградарстве Украины / Под ред. А.М. Авидзба. - Ялта: ИВиВ «Магарач», 2004. - 264 c.

Metodicheskie rekomendatsii po agrotekhnicheskim issledovaniyam v vinogradarstve Ukrainy [Guidelines for agrotechnical research in the viticulture of Ukraine]/ [Und. the ed. of A.M. Avidzba]. - Yalta: Institute of grapes and wine Magarach, 2004. - 264 s. (in Russian)

11. Борисенко, М. Н. Усовершенствование методов диагностики и разработка системы оптимизации питания растений и управления уровнями урожаев и качества продукции применительно к винограду (Методические рекомендации) / М.Н. Борисенко, М.Р. Бейбулатов, Н.А. Тихомирова, Р.А. Буйвал и др. - Ялта: НИВиВ «Магарач», 2014. $-24 \mathrm{c}$.

Borisenko M.N., Beibulatov M.R., Tikhomirova N.A., Buival R.A. Metodicheskie rekomendatsii «Usovershenstvovanie metodov diagnostiki i razrabotka sistemy optimizatsii pitaniya rastenij $i$ upravleniya urovnyami urozhaev $i$ kachestva produktsii primenitel'no $k$ vinogradus [ Improvement of diagnostic methods and development of a system for optimizing plant nutrition and managing crop levels and product quality in relation to grapes (Methodical recommendations)]. Yalta: Institute of grapes and wine «Magarach». 2014. 24 p. (in Russian)

12. Простосердов, Н.Н. Изучение винограда для определения его использования / Н.Н. Простосердов. - М.: Пищепромиздат. 1963. $-79 \mathrm{c}$.

Prostoserdov N.N. Izuchenie vinograda dlya opredeleniya ego ispol'zovaniya [Study of grapes to determine its use ]. Moscow: Pishchepromizdat. 1963. 79 p. (in Russian) 